\title{
Slips, Trips and Falls among the workers in a garment industry in Dhaka, Bangladesh
}

\author{
Rubel AKM ${ }^{1}$, Sultana $\mathrm{S}^{2}$, Alam AKMMU ${ }^{3}$, Nizam $\mathrm{S}^{4}$, Yasmin $\mathrm{R}^{4}$, Faruquee $\mathrm{MH}^{5}$, Ahmad $\mathrm{SA}^{6^{*}}$,
} ${ }^{1}$ Research fellow, ${ }^{2}$ Lecturer, ${ }^{3}$ Adjunct faculty, ${ }^{4}$ Assistant Professor, ${ }^{5}$ Associate Professor, ${ }^{6}$ Professor, Dept of Occupational and Environmental Health, Bangladesh University of Health Sciences (BUHS)

\section{ABSTRACT}

Introduction: Slips, trips, and falls (STFs) lead to considerable accidents and injuries with a large financial consequence. In garment industries, occupational accidents and injuries are not uncommon and slips, trips, and falls are the major contributory factors. It aimed to find out the contributing factors of slips, trips, and falls among the garment workers in Bangladesh.

Methods: This cross-sectional study was conducted in a garment industry to find out the factors responsible for slips, trips, and falls among the workers. The study participants were garment workers with one year of experience, regardless of age and sex. A total of 208 workers was selected by simple random sampling. The study was conducted from July 2018 to June 2019.

Results: Among the total 208 respondents, 130 (62.5\%) were female and the mean age was $27.49 \pm 7.18$ years. The majority of the respondents (57.2\%) had a primary level of education and had work experience up to five years $(71.6 \%)$. Of the total respondents, $62(29.8 \%)$ had the experience of slips, trips, and falls (STFs) in the last six months. Among them, slips were experienced by $34(16.3 \%)$, trips by $43(20.7 \%)$ and falls by $40(19.2 \%)$ respondents. Poor housekeeping 23(53.6\%), mopped wet floor 18(52.9\%), slopped and slippery floors 14(35.0\%), improper storage $14(32.6 \%)$, uneven floor $12(30.0 \%)$ and spilling of drinks $9(26.5 \%)$ in a higher proportion were responsible for slips, trips and falls. The ergonomic factors which were reported to contribute to slips, trips and falls in a higher proportion were working posture 30(69.8\%) and load-bearing $24(60 \%)$. Workplace stress, on the other hand, was found to be the most common $37(92.5 \%)$ contributing factor to slips, trips and falls.

Conclusion: Nearly two-thirds of garment workers experienced slips, trips and falls in their workplace. To prevent slips, trips and falls, steps should be taken to reduce the contributing factors, especially the workplace stress among the workers.

Key words: Bangladesh, Garment Worker RMG, Slips, Trips and Falls (STFs)

\section{Introduction}

A ccording to a recent International Labour Organization (ILO) report, each year, more than 2.78 million people die as a result of work-related injuries and 2.4 million (86.3\%) die as a result of work-

\section{DOI: https://doi.org/10.3126/ijosh.v11i1.36062}

Date of submission: 26.03.2021

Date of acceptance: 17.04 .2021

\section{Corresponding Author}

Professor Sk Akhtar Ahmad

Department of Occupational and Environmental Health,

Bangladesh University of Health Sciences (BUHS),

125/1, Darus Salam, Mirpur-1, Dhaka-1216, Bangladesh

E-mail: anon@bdcom.com, Cell phone: +8801552465730

ORCID ID: https://orcid.org/0000-0003-0025-2673 related diseases. Also, there are about 374 million non-fatal work-related injuries and illnesses each year, resulting in absences from work for more than four days. The expenditure of this everyday injury and illness is enormous and the financial burden of poor occupational health and safety practices is estimated at 3.94 percent of the worldwide Gross Domestic Product. ${ }^{1-4}$ As per the Labor Force Survey 2013 of Bangladesh, around 49 percent of people experiencing occupational injuries, 27 percent experienced dislocation, sprain, strain, and amputation, while 11 per cent confronted fracture..$^{5}$ ILO estimation in 2017, revealed that in Bangladesh every year, more than 11,000 workers get fatal accidents and

\section{c) (i) (8)}

This journal is licensed under a Creative Commons AttributionNon Commercial 4.0 International License. 
24,500 die due to work-related diseases and 8 million workers experience work-related injuries. ${ }^{6}$

Occupation-related slips, trips and falls (STFs) are a challenging issue, with considerable accidents and financial consequences revealed all over the world. STFs are considered the major sources of workplace injuries. Workers are influenced by STFs, leading to loss workdays, depending on their occupation and even the type of work equipment. ${ }^{7-9}$ Occupational STFs which include falls on the same level, and to a lower level, and slips, trips, and loss of balance without fall are the significant contributor to the national burden of occupational injury and costs paid in compensation. In the USA, STFs occurrences were the second most prevalent $(24.2 \%)$ cause of lost workdays (LWD) injury among workers in the private industry. ${ }^{10}$ In Canada, more than 42000 are injured as a result of falls each year, which contributed to $18 \%$ of time-loss injuries. ${ }^{11}$ STFs reported to cause about one-quarter of all onthe-job injuries and contribute about $67 \%$ of the top ten disabling workplace injuries like strains, sprains, and overextension injuries. ${ }^{12}$ According to the European Commission report among 1.16 million non-fatal occupational accidents, $17.4 \%$ were due to fall on the same level causes on average 10 work-days lost. Also, $4.4 \%$ were without fall but had slips and trips leading to injuries like a back injury resulting average of 11 workdays lost. ${ }^{7}$

Bangladesh is now in a mega-development system in which the economy of the country has to depend more on the industry. But this development is linked to various challenges, including the scope of occupational health and safety issues. Nature and degree of occupational accident and injuries is an important indicator of the state of Occupational Safety and Health $(\mathrm{OSH})$ in the industrial sector. A recent report revealed an increased workplace death due to accidents in Bangladesh. It was reported that in 2016 the worker's death due to workplace accidents was 699 which had been increased to 784, 1020 and 1200 in 2017, 2018 and 2019 respectively. ${ }^{13}$ Many accidents and injuries could be avoided if the conceivable hazards of a work environment could be identified ahead of time and if proper preventive measures are taken. 5,11,14

The ready-made garment industry in Bangladesh started its excursion in 1978. Presently trading readymade apparels including woven, knit, and sweater pieces of clothing which developed terrifically to turn into a multi-billion USD export sectors and a significant source of foreign exchange, account for about $80 \%$ of the total export and $17 \%$ of the GDP of the country. ${ }^{15,16}$ There are about 5400 garment industries, employs about 4.5 million workers, of whom about $85 \%$ are women. ${ }^{15}$ Bangladesh became one of the main exporters of ready-made garments worldwide and hence this area gives the stature commitment to expanding the economy of Bangladesh. ${ }^{17}$

In Bangladesh, laborers are legally ensured against occupation-related accidents and injuries through Bangladesh Labour Act, 2006, and Bangladesh Labour (Amendment) Act, 2013. The Labour Act 2013 has made a big number of amendments to the Bangladesh Labour Act, 2006. It has likewise presented several arrangements for improving workplace safety. At the point when a physical injury happens, the compensation is not always adequate to cover the misfortune, either loss of working hours, outcomes of minor or significant injuries or even demise. In studies, the garment workers perceived that they have to work in several hazardous conditions, and they are at risk of various occupational accidents and injuries and illnesses due to exposure to hazardous conditions in the garment industry. ${ }^{15,16,18}$ Bangladesh is moving with rapid industrialization for its economic development, but workplace safety must be ensured which cannot be disregarded. This study was an endeavor to find out the contributing factors of STFs among the garment workers, the result can be used to undertake preventive measures to provide safety to some extent.

\section{Methods}

This cross-sectional study was carried out in a selected garment industry located in Narayanganj, Dhaka, Bangladesh. The study was conducted from July 2018 to June 2019. Garment workers who had at least one year of working experience in the selected industry were the study population. A list of garment workers having one year of experience was obtained from the authority. The sample size was calculated by using the formula $n=z^{2} p q / d^{2}$, with $14.4 \%$ prevalence. ${ }^{19}$ The final sample size was 208 with the addition of a $10 \%$ non-response rate. From the list, 208 respondents, regardless of age and sex were selected by simple random sampling technique. Data were collected through face to face interview by using a pre-tested questionnaire. Respondent workers were asked if they experienced any STFs in the workplace in the previous six months. The collected data were 
analyzed according to the objectives of the study and predesigned variables. Frequency, mean and standard deviation were performed for descriptive statistics. To find out the association between STFs and socio demographic characteristics and job experience, chisquare was done. For the level of significance, the $p$-value was set at 0.05 . The ethical approval of the study was obtained from the ethical review committee of the Bangladesh University of Health Sciences.

\section{Results}

Among the total 208 respondents, $62.5 \%$ were female and $37.5 \%$ were male. Among them, the majority were 25 years and above, and overall, the mean age was $27.49 \pm 7.18$ years. A majority $(57.2 \%)$ of the respondents had a primary level of education (Table1). Among the respondents, $71.6 \%$ had working experience up to 5 years and the mean was $5.00 \pm$ 2.673 years. Of them, a majority $(62.0 \%)$ were found to work in the swing section and $12 \%$ to $13 \%$ were found to work at the cutting, finishing and ironing section. Around two-thirds $(64.4 \%)$ of the respondent had to work in sitting posture and the rest $(35.6 \%)$ had to work in standing posture. More than one-third (39.4\%) worked daily 10 hours and above (Table-2).

Of the total respondents, $29.8 \%$ had experience of STFs in the previous six months. Among them slips were $16.3 \%$, trips were $20.7 \%$, and falls was $19.2 \%$. (Table-3). Five percent (3) of the STFs, were reported to be hospitalized for not more than 3 days and $8 \%$ (5) received outdoor treatment because of injuries.

Regarding socio-demographic characteristics, it was found that the occurrence of STFs (44.9\%), slips $(25.6 \%)$, trips $(35.9 \%)$, and falls $(33.4 \%)$ were significantly higher among the male workers and more common in the younger age group (up to 24 years), while among the respondents who had primary levels of education the occurrence was low. For the respondents who had monthly income up to Taka 13000, the occurrence was significantly high and for those who had income $>13000$ to 18000 , the occurrence was significantly less. The respondents with an overweight significantly higher proportion had the experience of STFs $(36.5 \%)$, slips and trips $(21.2 \%)$. On the other hand trips (27.9\%) and falls (25.2\%) were significantly higher among the respondents with normal weight (Table-4).

Concerning job experience, STFs were found comparatively higher among the respondents who had a job year more than 5 , while among the respondents up to five years job, the occurrence of slips was high $(19.3 \%)$. Respondents worked in ironing section STFs (53.8\%), slips (26.9\%) and trips (34.6\%) were found significantly higher and falls(35.7\%) was found higher among the workers working in the finishing section. The respondents worked daily 10 hours and more, the occurrence of STFs $(69.0 \%)$, slips $(33.7 \%)$, trips $(37.3 \%)$ and falls $(44.6 \%)$ was significantly higher. Further, the respondents who worked in standing posture, the STFs (44.6\%), slips (24.3\%), trips (32.4\%) and falls $(32.4 \%)$ were also found significantly higher (Table-5).

The factors responsible for the occurrence of slips, trips, and falls as reported by the respondents were categorized as physical, ergonomic, and psycho-social factors. The ergonomic and psycho-social factors were common in all the occurrences. However, slips $(67.6 \%)$ and trips (69.8\%) were found common among the workers who worked in long working posture (long standing and sitting posture) and falls (60.0\%) were common in load-bearing. The most common psychosocial factor was stress, found in a higher proportion in all the incidents of slips $(90.1 \%)$, trips $(72.1 \%)$ and falls $(92.5 \%)$, while fatigue was only found in those who had trips $(4.7 \%)$ (Table-6). The common physical factors which were responsible to cause slips were mopped the wet floor $(52.9 \%)$, spillage of drinks on the floor (26.5\%), footwear without slip resistance (14.7\%) and wet floor due to rainwater $(11.7 \%)$. The most common physical factors to cause trips was poor housekeeping (53.5\%), and the next factors were improper storage/ stacks $(32.6 \%)$ and obstacle walkway (18.6\%). The common physical factors responsible to cause falls were sloped surface and slippery surface (35.0\%), uneven and floor holes $(30.0 \%)$, poor illumination $(17.5 \%)$, and unprotected edges/unmarked (15.0\%) (Table-7). 
Table 1: Socio-demographic characteristics of the respondents $(n=208)$

\begin{tabular}{lccc}
\hline Variables & & Frequency & Percentage \\
\hline \multirow{2}{*}{ Sex } & Male & 78 & 37.5 \\
& Female & 130 & 62.5 \\
& Upto 24 & 86 & 41.3 \\
& $25-29$ & 42 & 20.2 \\
Age (Years) & $30-34$ & 36 & 17.3 \\
& $\geq 35$ & 44 & 21.2 \\
& Mean \pm SD & & $27.49 \pm 7.18$ years \\
Education Level & Primary Level & 119 & 57.2 \\
Monthly income (Taka) & Secondary Level & 89 & 42.8 \\
\hline
\end{tabular}

Table 2: Job experiences of the respondents $(n=208)$

\begin{tabular}{lccc}
\hline Job experiences & & Frequency & Percentage \\
\hline \multirow{2}{*}{ Years of Job } & Up to 5 years & 149 & 71.6 \\
& Above 5 years & 59 & 28.4 \\
& Mean \pm SD & & $5.00 \pm 2.673$ years \\
Working Sections & Cutting & 25 & 12.0 \\
& Swing & 129 & 62.0 \\
& Finishing & 28 & 13.5 \\
Wroning & Standing & 26 & 12.5 \\
Working Posture & Sitting & 74 & 35.6 \\
Working Hours & Up to 9 & 134 & 64.4 \\
\hline
\end{tabular}

Table 3: Distribution of respondents by occurrence of Slips, Trips and Falls

\begin{tabular}{ccc}
\hline Incident & Frequency & Percent \\
\hline STFs* $^{*}$ & 62 & 29.8 \\
Slips & 34 & 16.3 \\
Trips & 43 & 20.7 \\
Falls & 40 & 19.2 \\
\hline
\end{tabular}

*Multiple Occurrences

Table 4: STFs, Slips, Trips and Falls of the respondents by Socio-demographic characteristics

\begin{tabular}{|c|c|c|c|c|c|c|}
\hline \multicolumn{2}{|c|}{ Characteristics } & \multirow{2}{*}{$\begin{array}{c}\text { Slips } n=34 \\
20(25.6)\end{array}$} & \multirow{2}{*}{$\begin{array}{c}\text { Trips } n=43 \\
28(35.9)\end{array}$} & \multirow{2}{*}{$\begin{array}{l}\text { Falls } \mathbf{n}=40 \\
26(33.4)\end{array}$} & \multirow{2}{*}{$\begin{array}{c}\begin{array}{c}\text { STFst } \\
\mathrm{n}=62\end{array} \\
35(44.9)\end{array}$} & \multirow{2}{*}{$\begin{array}{c}\text { Significance } \\
\text { Test } \\
p=000^{*}\end{array}$} \\
\hline Sov & Male & & & & & \\
\hline sex & Female & $14(10.8)$ & $15(11.5)$ & $14(10.8)$ & $27(20.8)$ & \\
\hline \multirow{4}{*}{ Age (Years) } & Upto 24 & $18(20.9)$ & $23(26.7)$ & 22 (25.6) & $31(36.0)$ & \multirow{4}{*}{$p=.119$} \\
\hline & $25-29$ & $6(14.3)$ & 7 (16.7) & 5 (11.9) & $11(26.2)$ & \\
\hline & $30-34$ & $7(19.4)$ & $6(16.7)$ & 8 (22.2) & $12(33.3)$ & \\
\hline & $\geq 35$ & $3(6.8)$ & 7 (15.9) & $5(11.4)$ & 8 (18.2) & \\
\hline \multirow{2}{*}{ Education } & Primary & $18(15.1)$ & 23 (19.3) & 22 (18.5) & $33(27.7)$ & \multirow{2}{*}{$p=.449$} \\
\hline & Secondary & $16(18.0)$ & $20(22.5)$ & $18(20.7)$ & $29(32.6)$ & \\
\hline
\end{tabular}




$\begin{array}{ccccccc}\text { Monthly } & \leq 13000 & 27(21.4) & 29(23.0) & 28(22.2) & 44(34.9) & \\ \text { Income } & 13000-18000 & 4(8.2) & 6(12.2) & 5(10.2) & 7(14.3) & p=.025^{*} \\ \text { (Taka) } & 18000+ & 3(9.1) & 8(24.2) & 7(21.2) & 11(33.3) & \\ & \text { Under Weight } & 2(4.4) & 1(2.2) & 2(4.4) & 4(8.9) & \\ \text { BMI } & \text { Normal Weight } & 21(18.9) & 31(27.9) & 28(25.2) & 39(35.1) & p=.002^{*} \\ & \text { Over Weight } & 11(21.2) & 11(21.2) & 10(19.2) & 19(36.5) & \end{array}$

${ }^{\dagger}$ Test of significance was done within STFs

* Significant

Table 5: Distribution of STFs, Slips, Trips and Falls of the respondents by their job experiences

\begin{tabular}{|c|c|c|c|c|c|c|}
\hline \multicolumn{2}{|l|}{ Job experiences } & $\begin{array}{l}\text { Slips } \\
n=34\end{array}$ & $\begin{array}{l}\text { Trips } \\
n=43\end{array}$ & $\begin{array}{l}\text { Falls } \\
n=40\end{array}$ & $\begin{array}{c}\text { STFst } \\
n=62\end{array}$ & $\begin{array}{c}\text { Significance } \\
\text { Test }\end{array}$ \\
\hline Job & Up to 5 & $29(19.3)$ & $30(20.0)$ & $28(18.7)$ & $42(28.0)$ & \multirow{2}{*}{$p=.359$} \\
\hline Years & Above 5 & $05(8.6)$ & $13(22.4)$ & $12(20.3)$ & $20(34.6)$ & \\
\hline \multirow{4}{*}{ Working Section } & Cutting & $4(16.0)$ & $5(14.7)$ & $7(28.0)$ & $9(36.0)$ & \multirow{4}{*}{$p=.010^{*}$} \\
\hline & Swing & $17(13.2)$ & $19(14.7)$ & $17(13.2)$ & $29(22.5)$ & \\
\hline & Finishing & $6(21.4)$ & $10(35.7$ & $7(25.0)$ & $10(35.7)$ & \\
\hline & Ironing & $7(26.9)$ & $9(34.6)$ & $9(34.6)$ & $14(53.8)$ & \\
\hline \multirow{2}{*}{ Working Hours } & Up to 9 & $6(4.8)$ & $6(4.8)$ & $9(7.2)$ & $13(10.4)$ & \multirow{2}{*}{$p=.000^{*}$} \\
\hline & $\geq 10$ & $28(33.7)$ & $37(44.6)$ & $31(37.3)$ & $49(69.0)$ & \\
\hline \multirow{2}{*}{ Working Posture } & Standing & $18(24.3)$ & $24(32.4)$ & $24(32.4)$ & $33(44.6)$ & \multirow{2}{*}{$p=.001^{*}$} \\
\hline & Sitting & $16(11.9)$ & $29(14.2)$ & $16(11.9)$ & $29(21.6)$ & \\
\hline
\end{tabular}

†Test of significance was done within STFs

* Significant

Table 6: Distribution of respondents by ergonomic and psycho-social factors by Slips, Trips and Falls

\begin{tabular}{lcccc}
\hline Factors & & Slips $\mathbf{n = 3 4}$ & Trips $\mathbf{n = 4 3}$ & Falls $\mathbf{n = 4 0}$ \\
\hline \multirow{2}{*}{ Ergonomical } & Load bearing & $11(32.4)$ & $13(30.2)$ & $24(60.0)$ \\
& Work posture & $23(67.6)$ & $30(69.8)$ & $16(40.0)$ \\
Psycho-Social & Stress & $30(90.1)$ & $31(72.1)$ & $37(92.5)$ \\
& Weakness & $4(11.8)$ & $10(23.2)$ & $3(7.5)$ \\
\hline
\end{tabular}

Table 7: Distribution of the respondents by physical factors responsible for Slips, Trips and Falls

\begin{tabular}{|c|c|c|c|c|c|c|}
\hline \multirow[t]{2}{*}{ Factors } & \multicolumn{2}{|l|}{ Slips n=34 } & \multicolumn{2}{|c|}{ Trips $n=43$} & \multicolumn{2}{|c|}{ Falls $n=40$} \\
\hline & Spillage of drinks & $9(26.5)$ & $\begin{array}{c}\text { Poor } \\
\text { housekeeping }\end{array}$ & $23(53.5)$ & $\begin{array}{c}\text { Slippery/ Sloped } \\
\text { surface }\end{array}$ & $14(35.0)$ \\
\hline \multirow{4}{*}{$\begin{array}{l}\text { Physical } \\
\text { Factor }\end{array}$} & Spillage of oily substance & $3(8.8)$ & $\begin{array}{c}\text { Improper } \\
\text { storage/ stack }\end{array}$ & $14(32.6)$ & $\begin{array}{c}\text { Floor holes/ } \\
\text { uneven }\end{array}$ & $12(30.0)$ \\
\hline & Mopped wet floors & $18(52.9)$ & $\begin{array}{l}\text { Obstacle } \\
\text { pathway }\end{array}$ & $8(18.6)$ & $\begin{array}{l}\text { Unprotected } \\
\text { edges }\end{array}$ & $6(15.0)$ \\
\hline & Wet floors by Rain water & $4(11.7)$ & Other & $2(7.5)$ & Poor illumination & $7(17.5)$ \\
\hline & $\begin{array}{l}\text { Footwears without slip } \\
\text { resistant }\end{array}$ & $5(14.7)$ & - & - & $\begin{array}{l}\text { Unsafe position of } \\
\text { ladder }\end{array}$ & $2(5.0)$ \\
\hline
\end{tabular}

* Multiple response

\section{Discussion}

STFs are common incident within the workplace, which can lead to minor to fatal accidents and injuries, as well as permanent disability of the workers. The majority of those are caused by falls at the same level, as a result of slipping on wet, oily, or powdery or hazardous surfaces or floors, tripping on the objects, or keeping wrong steps on uneven surfaces or obstruction in walkways, poor lighting and poor housekeeping. 
Sprains of the hand, wrist, or ankle and back strains, are the most common injuries caused by falls. Falls to a lower floor, such as from loading docks, stairways, ladders or height, etc. may result in far more severe injuries, including fractures and death. 11,12,14,20 This cross-sectional study was conducted among 208 garment workers in a selected factory showed that near two-thirds $(29.8 \%)$ had the experience of STFs. Among the STFs, the occurrence of trips $(20.7 \%)$ and falls $(19.2 \%)$ was more common than slips $(16.3 \%)$. Factors that were identified as a cause for STFs were categorized as physical factors, ergonomic factors and psycho-social factors. Stress was found to be the most common factor contributing to STFs $(90.1 \%, 72.1 \%$ and $92.5 \%$ respectively). This study further revealed that the long working posture was also a common contributing factor to STFs (67.6\%, $69.8 \%$ and $40.0 \%$ respectively). Among the physical factors, mopped wet floors $(52.9 \%)$ was the most common factor responsible for slips. Other factors responsible for slips were spillage of drinks on the floor (26.5\%) and footwear without slip resistance $(14.7 \%)$. The common factors responsible to cause trips were poor housekeeping (53.5\%) and improper storage/stack (32.6\%). Factors that led to falls included sloped surface and slippery surface $(35.0 \%)$, uneven and floor holes $(30.0 \%)$ and poor illumination $(17.5 \%)$. Moreover, this study revealed that a few of the respondents got injuries because of STFs and none of the injuries was severe. Studies revealed that STFs are preventable in the workplace if measures are taken for good housekeeping, the good order of floor surface, slip-resistant footwear, immediate elimination of spilled liquids including water, obstacles fewer walkways, and a good stack of materials. ${ }^{11,12,14,20}$

In Bangladesh's garment factories, the majority of the workers are females and young adults and have minimum education. ${ }^{7,18}$ In the current study, female workers were also more (62.5\%) and more than half being over 25 years and had primary education. Employers of garment factories did not prefer the aged-experienced workers in the factories. According to studies, since the salary of the experienced workers is higher whereas the salary of new workers is lower, thus lowering the cost. Additionally, employers could pay female workers less than male workers, because female workers with minimal education are easily available. ${ }^{21,22}$ However, studies found that females had a higher rate of occurrence of slips, trips, and fall than males, and STFs were significantly higher among older experienced workers than younger workers. ${ }^{7,23,24}$ But this study revealed the more common occurrence of STFs among the male workers and within the younger age groups, the reasons are not clear and that needs to be explored further. This study also found that the garment workers who had obesity or overweight had a significant tendency to increased occurrence of STFs (36.5\%). In the studies also, a similar tendency of occurrence of STFs among the obese, with an increased rate of STFs with increased BMI were reported. ${ }^{25,26}$

Regarding job factors, the present study showed that daily working hours, working sections and working posture were all associated with the increased occurrence of STFs. Further, this study revealed that workers except for the swing section, workers worked daily 10 hours and above, and workers worked in longstanding posture, all had significantly an increased tendency to STFs. Job factors such as working hours, working sections and working posture, have been documented elsewhere to cause job stress among workers. ${ }^{27-29}$ Workplace stress on the other hand was reported to contribute and increase the STFs incidents. ${ }^{28}$ For preventions of STFs within the garment factory, also, to get rid of physical, ergonomic and psychosocial contributing factors, special measures should be undertaken to prevent workplace stress.

\section{Conclusion}

In this study, STFs in the workplace were reported among near two-third of the garment workers. A variety of factors that contribute to STFs had been reported, but workplace stress was found to be the most common factors. It was found that male and younger workers comparatively had more experience of STFs. Workers working daily ten hours or more and in long-standing posture had a higher contribution in the occurrence of STFs. To prevent STFs within the garment factory, measures should be undertaken to remove the contributing factors revealed in this study, especially the workplace stress among the workers.

Conflict of Interest: None 


\section{References}

1. International Labour Organization. Safety, Health at Work [Internet]. Geneva, Switzerland: International Labour Organization (ILO);1996-2021 [Assessed on February 10, 2021]. Available from https://www.ilo. org/global/topics/safety-and-health-at-work/lang--en/ index.htm

2. International Labour Organization. Introduction and Safety [Internet]. International Labour Organization; 1996-2021 [Assessed on February 10, 2021]. Available from https://www.ilo. org/global/topics/ labour-administration-inspection/resources-library/ publications/guide-for-labour-inspectors/introduction/ lang--en/index.htm.

3. Denis EG. Our world with ISO 45001 [Internet]. ISOfocus. 2018 March 18 [Assessed on July 10, 2019]. Available from https://www.iso.org/news/ ref2268.html

4. International Labour Organization. Improving the Safety and Health of young workers [Internet]. Geneva, Switzerland: International Labour Organization (ILO); 2018 [Assessed on July 10, 2019]. Available from https://www.ilo.org/wcmsp5/groups/public/-ed_ protect/-protrav/-safework/documents/ publication/ wcms_625223.pdf

5. Ahmed N. Occupational injury in the industry sector: Where do we stand? [Internet]. The Financial Express. 2017 November 16[Assessed on July 10, 2019]. Available from https://thefinancialexpress. com.bd/views/occupational-injury-in-the-industrysector-where-do-we-stand-1510845531

6. International Labour Organization. Safety and Health at work in Bangladesh[Internet]. Dhaka, Bangladesh: International Labour Organization (ILO); 2017[Assessed on July 10, 2019]. Available from: https://www.ilo.org/dhaka/Areasofwork/safety-andhealth-at-work/lang--en/index.htm

7. Chang WR, Leclarcq S, Lockheart TE, Haslam R. State of Science: occupational slips, trips and falls at the same level. Ergonomics. 2016;59(7):861-83

8. Han T. Yeoh, Thurmon EL, Xuefang Wu. Non-fatal occupational falls on the same level. Ergonomics. 2013;56(2):153-65.

9. Leclercq S, Thouy S. And Progress in understanding processes underlying occupational accidents on the level based on case studies. Ergonomics. 2004;47(12):1282-300.

10. Amandus $\mathrm{H}$, Bell J, Tiesman $\mathrm{BH}$ and Biddle $\mathrm{E}$. The epidemiology of slips, trips and falls in a Helicopter Manufacturing Plant. Human Factors. 2012;54(3):387-95.

11. Canadian Centre for Occupational Health and Safety. OHS Answers Fact Sheets[Internet]. Prevention of Slips, Trips and Falls. Canada: Canadian Centre for Occupational Health and Safety (CCOHS);
2018[Assessed on July 10, 2019]. Available from https://www.ccohs.ca/oshanswers/safety_haz/falls. $\mathrm{html}$

12. Slips, Trips and Falls: A Heavy Toll on your Workers and your Bottom line [Internet] ErgoScience. 2014[Assessed on July 10, 2019]. Available from https://www.ergoscience.com/hubfs/ES_eBook_ SlipsTripsFalls.pdf

13. BILS. Bangladesh faced 593 labour unrests in 2020[Internet]. The Daily Observer. January 10, 2021[Assessed on February 10, 2021]. Available from https://www.observerbd.com/ news. php? id=293426

14. Workplace Safety \& Prevention Services. Preventing Slips, Trips, and Falls[Internet]. Workplace Safety \& Prevention Services (WSPS); 2013[Assessed on July 10, 2019]. Available from https://www.wsps.ca/ WSPS/media/Site/Resources/Downloads/WSPS_ PrevSlipsTripsFalls-2013_FinalloRes.

15. Khandker S, Ahmad SA, Khan MH, Faruquee MH, Yasmin R, Dutta $S$, et al. Perceived workplace hazards and health problems among the workers of garment factory in Dhaka. J Preventive Social Medicine (JOPSOM). 2016;35(2):1-9.

16. Ferdous, KJ, Sultana, R and Islam, L. Occupational Health of the Garment Workers in Bangladesh. J Environment. 2014;1(1):21- 4.

17. Rahman HM, Siddiqui SA. Female RMG worker: Economic Contribution in Bangladesh. Int J Scientific Research Publication. 2015;5(9):1-9

18. Khan NR, Dipti TR, Ferdousi SK, Hossain MZ, Ferdousi S, Sony SA, Ahmed S, Paul N, Islam MS. Occupational Health Hazards among Workers of Garment Factories in Dhaka City, Bangladesh. J Dhaka Med Coll. 2016;24(1):36-3

19. Bureau of Labor Statistics. Economic News Relaese. Table-5, Asian only[Internet]. Washington: US Bureau of Labor Statistics; 2015[Assessed on July 10, 2019]. Available from https://www.bls.gov/news.release/ osh2 t05.

20. Safe Work NSW. Slips, Trips and Falls: on the same level [Internet]. NSW: Australia; 2020[Assessed on October 10, 2020]. Available from https://www. safework.nsw.gov.au/hazards-a-z/slips-trips-andfalls-on-the-same-level

21. War on Want. Stitched-up-Women workers in the Bangladesh garment sector [Internet]. 44-48 Shepherdess, London: War on Want. Walk; 2011 July[Assessed on July 10, 2019]. Available from https://waronwant. org/sites/default/ files/StitchedUp. pdf

22. Majumder PP, Begum A. The Gender Imbalances in the Export Oriented, Garment Industry in Bangladesh [Internet]. Working Paper Series No. 12, Policy Research Report. Dhaka: The World Bank; 2000 
June[Assessed on July 10, 2019]. Available from http: //www.worldbank.org/gender/prr.

23. Bell JL, Collins JW, Tiesman HM, Ridenour M, Konda S, Wolf L, Evanoff B. Slip, Trip, and Fall Injuries among Nursing Care Facility Workers. Workplace Health Safety. 2013;61(4):147-52.

24. Greenberg MR, Kane BG. Perceived Fall Risk and Functional Decline: Gender Differences in Patient's Willingness to Discuss Fall Risk, Fall History, or to have a Home Safety Evaluation. Yale J Biol Med. 2016;89(2):261-7.

25. Koepp GA, Snedden BJ and Levine JA. Workplace slip, trip and fall injuries and obesity. Ergonomics. 2015;58(5):674-9.

26. Black Y. Biomechanists explore effect of obesity on falls[Internet]. LER, Lower Extremity Review. 2016
February [Assessed on July 10, 2019]. Available from: https://lermagazine.com/article/biomechanistsexplore-effect-of-obesity-on-falls.

27. Akther S, Akter S, Uddin MK. Factors influencing job stress in Privatized banks of Bangladesh. Sona Global Management Review. 2017;11(1):1-17.

28. Canadian Centre for Occupational Health and Safety. OHS Answers Fact Sheets. Workplace Stress- General[Internet]. Canada: Canadian Centre for Occupational Health and Safety (CCOHS); 2018[Assessed on July 10, 2019]. Available from https://www.ccohs.ca/oshanswers/psychosocial/ stress.

29. Naqvi $S M H$, Khan MA, Kant $A Q$ and Khan $S N$. Job Stress and Employees' Productivity: Case of Azad Kashmir Public Health Sector. Interdisciplinary J Contemporary Res in Business. 2013;5(3):525-37. 